\title{
A Journey from Omdurman to Mombasa Viâ Lake Rudolf
}

\section{Author(s): H. H. Austin}

Source: The Geographical Journal, Vol. 19, No. 6 (Jun., 1902), pp. 669-688

Published by: geographicalj

Stable URL: http://www.jstor.org/stable/1775780

Accessed: 27-06-2016 15:55 UTC

\section{Your use of the JSTOR archive indicates your acceptance of the Terms \& Conditions of Use, available at}

http://about.jstor.org/terms

JSTOR is a not-for-profit service that helps scholars, researchers, and students discover, use, and build upon a wide range of content in a trusted digital archive. We use information technology and tools to increase productivity and facilitate new forms of scholarship. For more information about JSTOR, please contact support@jstor.org.

The Royal Geographical Society (with the Institute of British Geographers), Wiley are collaborating with JSTOR to digitize, preserve and extend access to The Geographical Journal 


\section{The}

\section{Geographical Journal.}

No. 6.

JUNE, 1902.

VoL. XIX.

\section{A JOURNEY FROM OMDURMAN TO MOMBASA VIÂ LAKE RUDOLF."*}

By Brevet-Major H. H. AUSTIN, C.M.G., D.S.O., R.E.

ON October 27, 1900, I was offered the command of a survey expedition in the Sudan, and Major R. G. T. Bright, of the Rifle Brigade, who had twice previously accompanied me in Africa, was detailed to assist me in the undertaking. The next month was employed by us in equipping the expedition, which it was anticipated would be absent from England for about a year.

On our arrival at Cairo it was decided that a medical officer should accompany the expedition, and the services of Dr. J. Garner, who was then attached for military duty to the British troops, were obtained. That was on December 10, and on the 15th he had been completely fitted out, and ready to accompany us on our journey to Omdurman. We left for Assuan by train on the night of December 15, and arrived at Khartum on the night of December 23. During the next few days Colonel Talbot handed over to us the Jehadia-some half-dozen of whom had accompanied Major Bright and me the previous year when we visited Abyssinia_our transport animals, saddles, rifles, ammunition, tents, etc., etc., and, taking three months' supply of food with us, we started on our journey up the Nile to Nasser on December 29. The gunboat Fateh, which was our home for the next fortnight, towed two double-decked barges and two sailing-boats, in which all our animals, men, rations, equipment, etc., were accommodated. All told, we numbered sixty-two men, including ourselves, servants, escort, and transport drivers. We proceeded without incident up the Nile, reaching Fashoda

* Read at the Royal Gengraphical Society, April 14, 1902. Map, p. 788.

No. VI.-June, 1902.] 
on the night of January 6, Taufikia the next day, and thence continued up the Sobat river.

Nasser fort was reached by the expedition on the evening of January 11, and there we met Blewitt Bey, the Mudir of Fashoda, who accompanied us some 9 miles up the Sobat river the following day, to a point where it had been decided the expedition should disembark and continue the remainder of its journey by land. During the next two days all the transport animals, equipment, etc., of the expedition were landed, and the Mudir returned to Taufikia in his steamer on the morning of January 14, 1901, followed shortly after by the Fateh and the sandal and gyassas, which had brought us so far from Omdurman by water. We were cut off now from all communication with the outer world, of which we heard no news again until we reached the Lake Baringo post on August 2.

A start was made on the $17 \mathrm{th}$, and a most unsatisfactory one it was. Following the river for a mile, we struck across country to avoid a big bend, and at once became involved in long grass, which concealed great deep cracks in the ground caused by the drying up of the swamps. Into these cracks the poor little donkeys kept constantly putting their feet, and fell down in a most helpless state. It was often necessary to dig away round their feet in order to extricate them from the cracks in which they were firmly wedged. As a result, it was past 2 p.m. before we struck the river again and were able to camp, although we had only marched some 4 or 5 miles. The camp remained halted the next day, whilst a party was despatched to bring on the food left behind. In this way, proceeding easily by double stages, we travelled along the Sobat to its junction with the Pibor, and then struck south along the latter river, very much along the route followed by Major Bright and me the previons year, to the junction of the Gelo and Pibor rivers near the village of Bil. Here the Nuer guide obtained for us by Blewitt Bey desired to return to Nasser as he feared to proceed further. Sheikh Yowe and all his people, who during the rainy season inhabit the Koratong group of villages some 8 or 9 miles south-west of Bil, had moved to the latter place for the dry season. A deputation was therefore sent to Sheikh Yowe, asking that we might be provided with a guide to conduct us to the junction of the Akobo and Pibor rivers. In accordance with our request, he sent us one of his own sons; but this man gave us the slip soon after we started next day, and we never saw him again. Having previously traversed this portion of the journey, it did not very much matter, so we continued without a guide, and had little difficulty in reaching the Pibor-Akobo junction on February 4, 1901.

We had by this time consumed our surplus food, and were able to proceed direct; and were fortunate in finding some Anuak natives settled temporarily at the river junction, two of whom consented to 
guide us for a few days along the Akobo in return for presents of beads. On February 5, therefore, we started in an easterly direction along the Akobo, and two days later reached our old camping-ground of May 15, 1900, where Major Bright and I had first struck the Akobo when leaving the Gelo river. Travelling was somewhat laboured owing to the long grass not keing burnt by the natives, which is always done when it has become sufficiently dry to ignite readily. Hitherto, however, we had experienced little trouble from swamps; but we were soon to encounter these formidable obstacles, which caused great delay in working round them on higher ground away from the river. Indeed, more than once we were compelled to retrace our footsteps for sereral miles, as we were unable to proceed in the direction we desired to. Between February 9 and 16 we were unable to camp on the river at all, owing to broad belts of swamp, which effectually prevented us approaching the stream. Every night, therefore, we were obliged to camp on the edge of this swamp, where at sundown the mosquitoes appeared in myriads, and made one long for day. We had now reached the Anuak district of Tedo, and the guides wished us to cross the river at this point, as the travelling was reported better on the north or right bank of the river. We were separated from the main stream by a thick belt of tall coarse grass a mile wide and several swampy overflow channels, so Major Bright and Dr. Garner were employed on the 16 th in improving the approach to the river and the track on the far side. Thanks to this work being thoroughly well done, we had little difficulty in crossing on the $17 \mathrm{th}$, and continued in an easterly direction away from the river to high ground, where large numbers of Anuak huts were dotted about midst cultivation. All the natives, however, fled at our approach, and it was almost impossible to get them to come near us, in spite of our being accompanied by several of their fellowtribesmen from the opposite side of the river. To do our guides justice, they were the most accomplished looters I have had the pleasure of travelling with, and never hesitated for a moment, when they had the opportunity, of clearing out their own brothers' huts of all they possessed, unless prevented from doing so. Possession is most obviously nine-tenths of the law amongst these simple (?) savages.

Our next march south from Tedo was at some distance from the river, both banks of which were fringed with a broad belt of long grass and swamp as far as the village of Neum. Here we struck the river again, and camped in a most charming spot under giant sjcamores, of which there was almost a forest growth along the banks. Numerous Colobus monkeys found food and refreshment here, whilst many lovely birds and butterflies added colour to the scene, which was further enhanced by the pretty cotton-plant flowers-a pleasant change from the dreary swamp land, often devoid of even a single tree, to which we had become accustomed. From this point on the country is 
generally well wooded, although in many places bordering the river bank large areas of swamp exist. On February 22 we obtained our first view of a hill since we had left Nasser. This is a fine rugged isolated mountain, which attains a height of 3550 feet, and is known to the Anuaks as Ungwala. A long march of 16 miles on February 24 brought us to the foot of this hill, and we camped for the first time on gravelly soil, between it and the river.

I may here note that in Bòttego's map this mountain, called by him Ischeno, is shown on the wrong bank of the river. The next day we discovered two small lakes during the march, most picturesque pieces of water, which I named after my two comrades, Lakes Garner and Bright. The country now became more undulating, and although in many places the river-banks were clothed with long coarse grass, we were always able to proceed without much difficulty along the higher ground overlooking the river. On several occasions we saw herds of magnificent elephants, and on two separate days were compelled to halt the whole caravan in order to allow these majestic brutes to cross our path in front of us; this they did in a most leisurely way, causing something of a panic amongst our mules and camels, who little appreciated the proximity of these lordly beasts. During our last days on the Akobo river, much delay was caused by our having to cross from one bank to the other, as our guides would only take us by routes familiar to them. Fortunately, the water was seldom over knee-deep in these upper reaches of the river; but the banks were generally steep, and had to be especially prepared for the passage of our large number of transport animals.

On February 27 we camped for the last time on the river Akobo, which here flowed from an easterly direction before turning north. I estimated we were at the point where Bòttego in his map shows the large village of Melile. Of this place, however, we could find no trace, nor was the name even known to the guides who accompanied us. For some days past we had obtained glimpses in the early mornings of the lofty Abyssinian mountains away to the east of our route, the more important peaks of which I was able to fix approximately. The highest point was over 8000 feet above sea-level, whilst others ranged between 7000 and 8000 feet. I decided at this point to leave the Akobo river (which had previously been explored for some distance further up-stream by Bòttego, whose maps were very reliable), and to strike south along a small stream known to the Anuaks as the Ajibur, which, though at this time of the year was not running, still contained small pools at intervals. A small lake was formed a mile or two above the junction of the Akobo and Ajibur rivers.

On Februa:y 28 we crossed the Akobo, and, travelling for about 3 miles in a south-westerly direction across undulating country, struck the bed of the Ajibur, which we crossed and followed approximately 
for the next few days, always happily finding pools. To the west of our line of march isolated peaks sprang up at intervals, all of which were over 3000 feet in height. These and the ridge connecting them form, in my opinion, the water-parting between the Ajibur river and a stream reported by the Anuaks to exist some 15 to 20 miles to the west, which is known to them as the Neubari. Our guides had only heard of this stream, however, and had never visited it, I believe. Does such a river exist, I think it may possibly be identical with the late Captain Wellby's Ruzi II., as we had previously come across a swampy stream approaching very closely to the Akobo on February 21, which here was known to the Anuaks as the Oboth, and which they averred merely took off from the Akobo, some 10 miles distant. I have assumed in my map that the Neubari possibly enters the Oboth, and that the combined streams subsequently flow west to the Pibor, and not again into the Akobo.

On March 3 we camped for the last time in the plains before entering the hilly tract of country known as Boma. For the next few days our progress through these hills was extremely slow, as the track was in places very steep, and we were subjected to heavy rains, which not only converted the numerous little streams we had to cross into rapid mountain torrents, but also rendered the track very slippery, and in places boggy. Several streams, in fact, had to be bridged before we could cross our transport animals.

The scenery of this little mountain district was at times grand, as magnificent rocky crags and pinnacles were visible on nearly every side. 'The soil is an extremely fertile red loamy clay, and, I should say, capable of producing all kinds of cereals. The climate is delightful, the air being fresh and pure (as compared with the low-lying swamp land we had previously traversed); for all this country ranges from 3000 to 4000 feet above sea-level, whilst higher ridges and crags attain to almost an altitude of 6000 feet. The natives, though not unfriendly, are shy, as they are not only harassed by their more powerful neighbours to the south, such as the Magois and Karuno tribes, but the Abyssinians also pay them periodical visits. In consequence, on the approach of our caravan, they immediately concealed themselves, and it was with considerable difficulty that we eventually persuaded them that our intentions were friendly, and were able to procure a guide. On March 7 we crossed the highest ridge that the track led over, and then abruptly descended on the far side (from 3700 feet to 2600 feet) to the sloping glacis at the foot of the hills, which falls another 400 or 500 feet into the seeming dead level vast plain, extending as far as the eye could see, from the summit of the pass, away to the west-in fact, probably as far as the Nile and beyond. We now worked in a southwesterly direction to get out on to the plain, as the ground near the base of the mountain range (which ran north and south) was much 
broken up, and difficult for transport animals. We almost at once passed out of the rain zone, and were very shortly confronted with a barren desert.

In spite of large herds of zebra, hartebeeste, ostriches, and gazelle roaming these plains, which seemed to point to the fact that water must be plentiful somewhere, we experienced a most anxious time regarding this precious fluid. On March 11 we passed a large pool 6 or 7 miles after starting, but as it was too early in the day to camp, we proceeded, as we hoped to find water on ahead. By 2 p.m. we had marched $17 \frac{1}{2}$ miles, and were still in this burnt-up plain, and had found no traces of water. To continue with all our animals and the men showing signs of exhaustion seemed rash, as we had no one to tell us where water was likely to be found. The heat, too, had now become very great; so I decided to camp, unload all the animals to rest them, and to send off a search-party under Mabruk Effendi, accompanied by five camels and fifteen donkeys carrying saddles and water-skins. I instructed Mabruk Effendi to work in a westerly direction towards a prominent isolated craggy hill some 20 miles to the west of us, as I hoped by so doing, after marching some 7 or 8 miles, he might strike Wellby's Ruzi river No. II. The improvident men had early in the march emptied their water-bottles, but I did not feel disposed to return 10 or 11 miles along our track to the pool passed early in the day, as we should still have the difficulty regarding water ahead to face. It was a wretched afternoon, as there was not a drop of water in camp beyond what Major Bright, Dr. Garner, and I had in our water-bottles, and before long the great heat had such an effect on the men that the eyes of several of them literally appeared to bulge from their sockets.

Shortly before retiring to rest, a horrible idea seized me that we must be in the middle of the desert--where Mr. Donaldson Smith's expedition for three days had experienced such dreadful torture for want of water-in which case the Ruzi II. was here non-existent. I firmly believed then I had sent off the unfortunate search-party to their utter destruction, and could get no sleep in consequence, as none of them had returned. I sat up all night outside my tent in my chair, and as soon as the moon rose, shortly after midnight, I decided to send back another party of six men riding six donkeys, and taking all the men's water-bottles in camp, with orders to return to the pool some 10 miles distant, fill up, and come back as quickly as possible. This done, I felt at all events we could face the return journey to the pool on the morrow in the event of Mabruk Effendi and his men failing to find water, and be able, in addition, to spare a little for his exhausted party.

Morning dawned with not a cloud in sight. Anxious ejes scanned the western horizon, but not a trace of Mabruk Effendi's cavalcade could be seen. About seven, however, distant figures were observed, and through our glasses we made out camels, and later, donkejs and 
men. Their progress was very slow, and it was some time before we could see sufficiently clearly that the animals were carrying heavy loads. Then our hopes were raised indeed, for we knew that water must have been found. In due course, the men and animals, all dogtired, reached the camp. Mabruk Effendi had saved the situation by his indomitable pluck and determination, for, after a long weary search, he had come across a large swamp out on the plain, from which he had brought us gallons and gallons of water, as all the skins had been filled. We had more water than the men could drink now, for shortly after nine the other party sent back with water-bottles also arrived. We were able, in consequence, to give all the animals a taste of water each, and about 12.30 p.m. made a start for Mabruk Effendi's swamp, which fortunately proved to be only 7 or 8 miles distant. Even so, eight or ten men had so much felt the effect of being without water, that they were with difficulty got into camp before dark. It was a lesson, and a severe one; but it taught the men to be far more provident in the future regarding reckless drinking of water on the march. For what a fluke it had been that water was discovered in the direction I had indicated! Beyond that small area of swamp, it is not unlikely that no other water existed on that fearful desert plain.

We remained halted for March 13 and 14, to give men and animals ample time to recuperate, as we learnt from a small colony of natives settled on the swamp that there was a long march south before we would reach water again. Two of them consented to act as guides in return for presents of beads, so we made a fresh start on the 15 th, and, after a hot tiring march of 20 miles over this dreadful plain, struck a large pool in the Karuno river shortly before dark. Our guides would proceed no further, so for the remainder of our journey to Lake Baringo, except for a few days, when we were accompanied by Suk youths when approaching that place, we were left to our own devices. I decided at first, at all events, to follow this river in an easterly direction towards the hills, where there seemed more prospect of obtaining water than out on these inhospitable plains. We crossed the river on the 16th, and on the 17 th proceeded approximately along its bank, and later camped amidst a thick growth of thorn bush, in an old camp of either Dr. Donaldson Smith's or Captain Wellby's, where we obtained water by digging in the sandy bed of the nullah. We met large numbers of Karuno natives during this march, brilliantly decked out with fine ostrich feathers dyed different colours. I imagine they must be closely allied to the Magois people (first described by Dr. Donaldson Smith), who, we understood, had recently been driven further west by the powerful Turkana tribe; these had come north in force, and raided large numbers of cattle and goats and sheep, which they had succeeded in carrying off with them. The Karuno are not unfriendly, but extremely suspicious, so we had little opportunity of ascertaining much 
information from them, as they stoutly refused to provide us with guides.

The country lying to the east of us consisted of a thorny plain which extended to the foot of a precipitous-looking range of hills, a veritable rocky escarpment running north and south. It seemed, hopeless to attempt to climb this, so I decided to try and work round it in a southerly direction before proceeding east to our goal-Murle, on the river Omo. We struck south, therefore, on March 18, towards an isolated peak in the plain, and then turned south-east to a prominent outlying hill of the main range, where happily we found some small pools of water up on the hillside. Continuing round the foot of a rocky escarpment, generally in a south-easterly direction, next day we reached a dry khor, which seemed to promise water on digging. We were unable to find any. We had, however, sufficient water in skins to last the men for one day, so in the afternoon parties were sent out to search. One man eventually returned after dark, reporting the existence of a large pool some miles distant at the base of a large valley thickly wooded with thorn bush, and enclosed to the south by irregular ranges of hills. We were rather shut in by hills, through which I was anxious to find if a pass existed; so next day the camp remained halted, whilst Major Bright went with a party to fill our skins with water and bring it on animals to camp, and Dr. Garner I despatched to look for a pass where I thought there might possibly be one.

His report proved satisfactory; so next day, carrying water as usual, we had little difficulty in climbing the pass, and then continued as before along the foot of the rocky escarpment, until we reached a point where it abruptly ran back in a northerly direction for some 10 to 15 miles. Thence the range ran east and west and subsequently south again, forming a long narrow bay, as it were, enclosing an open plain swarming with game. We camped without water, but later ascertained the existence of a small stream with pools in the centre of this enclosed plain, to which we marched next day. On March 22 we continued in an easterly direction over an easy pass at the foot of a rocky crag, and camped some 5 or 6 miles further on in another plain, where we obtained water by digging in the sandy bed of a dry khor. From this point we obtained our first view of Mount Naita, a grand mountain mass terminating in a lofty conical peak, which attains a height of over 7000 feet. I had previously approximately fixed the position of this peak in my journey along Lake Rudolf in 1898, as it is visible from a great distance, and for the next five or six weeks we seldom lost sight of it.

For the next two days we travelled generally in a south-easterly direction, and were fortunate in striking pools of water. Being without guides in an absolutely unknown country, we had literally to feel our way over this plain, thickly wooded with thorn bush. The anxiety 
regarding water had told in some cases on the men, who appeared a bit unnerved, and performed their work in an apathetic manner, as though they anticipated disaster. For the next week we proceeded generally in a direction slightly to the north of east, through a somewhat hilly country, where the difficulties regarding water still continued, and placed us on several occasions in a most unenviable position. Fortune favoured us, however, and when affairs looked their blackest, something always turned up to relieve us of anxiety. Nevertheless, it was with no small satisfaction that, when we reached the Sacchi river on April 1, we found it a fine running stream-the first flowing water we had seen since the beginning of March, when we were in Boma country. By the irony of fate, later on the same day, when following this river we became involved in a most formidable swamp, around which we worked with considerable difficulty, and were unable to camp on the river at all. We eventually found a fairly dry spot amidst thorn bushes, and camped here near a pool.

The escarpment we had lately been skirting, I am inclined to think, must be the edge of a high-lying plateau, varying in height, probably, from 3000 to 5000 feet above sea-level. I inagine all that country to be healthy, possibly well watered and fertile, and very closely resembling Boma in general features. I am sure a most interesting field for exploration exists on those hilly regions, which we were compelled to avoid, encumbered as we were with transport animals.

For the next three or four days we followed approximately the course of the Sacchi, which was clearly marked by a broad belt of tall trees ; near the river a fine forest growth existed (the haunt of numerous elephants), which made it extremely difficult to find or reach the riverbank. On April 4 we camped on an open plain, the river-bank being here free from trees or vegetation, some 7 or 8 miles to the north of Mount Nakua, a familiar landmark of our previous visit to Lake Rudolf. I now knew that probably a 20 -mile march in a direction slightly south of east would bring us to the Murle district on the Omo river, and this march was successfully accomplished on April 6. On the eighth, we continued some 5 miles in an easterly direction to our well-defined camp of September 15, 1898, on which I closed my survey from the north. The result proved most satisfactory, as the new position obtained for this camp, working from Nasser as my base, agreed within half a mile of the previous position obtained by me in 1898, when working north from the Mombasa side.

Our food supply was running extremely short, in spite of our having for some time past greatly reduced the men's rations, so it was decided to proceed leisurely up the Omo, with the twofold object of buying from the natives and meeting the supplies which we hoped might be being conveyed south towards us, and were merely delayed by the heavy rains which about this time commenced. On the 9 th we marched 
north, into the Kerre district, halted there the 10th, but could not induce the natives to trade, so moved on again a little further north on the 11th and 12th. At the latter camp we halted for two days, but could obtain no food at all from the natives. The river-bank was extensively cultivated; but the grain was in a green condition, and would not be ripe for at least another two months. The higher we got up the river, the more backward became the crops. We now began to get extremely anxious, as we had very little food left; the natives either had none or were unwilling to barter what they had, and of the expected supplies we could learn nothing.

There was still one more chance of obtaining food, perhaps, in the Mursu district, further north again, as Dr. Donaldson Smith the previous year had purchased and reported plenty in that neighbourhood. We decided, therefore, to proceed there, and a miserable time we spent during the undertaking. We were subjected to terrific storms of rain, which converted the plain into bog, and formed shallow lakes of water all over the country, rendering our progress far from pleasant. When we reached the Omo by cross-country marches, cutting off a great bend of the river which flows in a north-easterly direction, we found ourselves confronted by most extraordinary broken ground-a bewildering labyrinth of low clay cliffs and depressions. Through this sort of country we proceeded for two days in a westerly direction, but were unable to camp on the river, which was fringed by an impenetrable forest growth, the ground being inundated with water. We struck two small lakes, on the margin of the larger of which we camped on April 19-a most picturesque sheet of water, first previously seen, I believe, by Dr. Donaldson Smith.

It was most confusing work hunting up a possible route through this broken country, and we were compelled to zigzag about in a most annoying manner in our endeavours to proceed west. The country seemed to be absolutely deserted except for a few stray natives, none of whom lived on the bank we were following; and as for food, we saw practically no signs of it, and consequently obtained none. In little over a year the country had changed from a fertile, well-populated district to a barren one. The rains continued with unabated fury, and seldom had any of us experienced such terrific storms at night as those to which we were now subjected. Our animals were beginning to show serious signs of breaking down, as the Sudan camels and donkeys are quite unaccustomed to this sort of weather.

It was obviously suicidal to proceed further north, as even here in the plains we were doing badly, and had we continued into hilly country and forest, with its attendant cold as well as rain, $I$ felt in a short time we should lose every animal we had. I decided, therefore, to return again to Murle, to see if during our absence the food supplies had arrived. Could I get no news of them by April 25, I had made up 
my mind that our only hope of salvation, seeing the extremely critical position we were placed in regarding food, was to immediately make south along the western shores of Lake Rudolf for the Ribo post, living as best we could on our transport animals. Before leaving Omdurman we had read Sir Harry Johnston's report from Uganda, in which it was stated that a post had been, or was shortly to be, established at that place. I frankly admit that I anticipated a loss of perhaps 25 per cent. of our men and about 50 per cent. of the animals in the undertaking; but in my most pessimistic mood I never imagined the dreadful loss of 75 per cent. of our personnel, which we actually suffered, nor the terrible experiences we were to undergo before reaching safety. By one long and one short cross-country march from Mursu we reached our old camp on the Omo, near where we first struck that river on April 6.

There was no news of the food supplies, so we rested on April 23 and 24. During this interval of rest, one of the transport drivers, who had been with Major Bright and me on a previous expedition, mysteriously disappeared. I have little doubt that, whilst out in charge of the donkeys when grazing, he had gone off on a marauding expedition by himself, and had been speared by the natives. Search-parties were sent out, but no trace of him was ever found, as his body had evidently been thrown into the river. Up to this time our losses in transport animals had been very slight, considering the little rest they had had. We still had 11 camels, 10 mules, and 114 donkeys; but about this time some of the camels began to sicken, and in a short time several died, probably from eating some poisonous herb.

All arrangements being completed for the journey south, we made an afternoon march on April 25, as I considered it unlikely we could accomplish a 20-mile march now to the Sacchi, owing to the soft boggy nature of the ground after the recent heavy rains. Next day we travelled well for the first 4 miles, and then became involved in a frightful bog, through which the animals were only taken with great difficulty, and on the far side of which we were compelled to camp. It occupied us the whole of the next day reaching the Sacchi, which was only done just before dark. We had taken three days to accomplish what three weeks before had only taken us one. We now found that the Sacchi had recently overtopped its banks, and the country had been converted into swamp. We travelled 3 or 4 miles along it next day in a southerly direction, and crossed to the west bank, where the going seemed to be better. We found it impossible, however, to work towards the north-west corner ef Lake Rudolf, owing to the swampy nature of the country, through which our animals were quite unable to travel. For the next five or six days, therefore, we were working round this swamp at the foot of the Lorusia range of mountains, some miles away to the west of the lake. I would here remark that several powerful streams during the rainy season flow from the west into the 
Sacchi river, which spills into a large area of swamp at the head of Sanderson gulf, before the shores of Lake Rudolf are actually reached. At one time it appeared extremely doubtful if we could continue south; but we were fortunately able eventually to follow a dry route, and on May 5 were camped on the bank of a khor, which I felt sure must be the one entering the lake near Lumian.

Here our first great calamity befel us, as three of our men were murdered not a mile from camp. The fact remained unknown to us until nearly 3 p.m., when news was brought into camp that a noncommissioned officer, an askari, and our cook were lying dead on the plain, having been speared by natives. The details of this treacherous attack will never be known, as the natives were not seen. On receipt of this shocking intelligence, I despatched Dr. Garner with camels and an escort of twelve men to bring in the bodies, which were buried outside camp just before dark. That night for the first time we saw a comet in the constellation of Orion, and several discussions took place amongst the superstitious ones as to whether its advent was a good or evil omen. I fancy the impression that it was an evil one for us was probably more generally favoured. At all events, that same night about 1.30 a.m., with the assistance of a full moon, a band of from forty to fifty warriors made a dash for the camp, yelling like demons as they charged. Fortunately, every man was sleeping on his post round the camp as usual, and as their nerves had been highly strung from the afternoon incident, the sentries were all on the alert and especially watchful.

As we were unable to construct a thorn zariba round the camp, the promptitude of the sentry in front of our three tents, which was the side attacked, probably saved our lives. Shouting for the guard to turn out, this man fired as he shouted, and in less time than it takes me to describe it the whole of this side of the camp were firing at the advancing foe. The latter were unable to face our rifles, and turned and fled without penetrating our line of men. It was one of the quickest and smartest pieces of work we had ever seen done, and I was very highly gratified to find the excellent fire-discipline observed by the men. There was no wild senseless waste of ammunition, and firing ceased directly the enemy disappeared, which I need hardly say is not always the case with native troops who have been suddenly alarmed at night. A second attack was also attempted by another body on the rear face of the camp, but they were easily driven back, leaving several spears which they had hurled into the camp, but which had done no damage. It now became most obvious that the natives of this district, who formerly in 1898 were quite friendly, were now bitterly hostile.

As we had never harmed them in any way, and were always most anxious to establish friendly intercourse with the natives we met, I can only think that this sudden change of feeling towards Europeans had been brought about by ill treatment subsequent to our former visit. 
The following morning we marched 2 to 3 miles in an easterly direction along the khor, and reached our old camp of September 8, 1898, at Lumian. The natives dogged our footsteps and followed on our flanks to Komogul, where we camped that day on the bank of a khor, from the bed of which we obtained water near the surface. As there were large numbers of natives lurking about among the trees and bush, we made our position defensible for the night, but were left unmolested. The next day we made only a short march, and camped for the first time on a low cliff overlooking the lake. As the country was fairly open, the natives did not venture to approach too closely, although they took up prominent positions for observation purposes, screened by bush. Continuing next day, we camped near the foot of an extinct volcano, Lubur by name, and here I was taken seriously ill with gastritis, which rendered me so weak that Dr. Garner advised a halt on May 9 and 10. We started again on the 11th, and travelled in a southerly direction along the lake-shore; but I was compelled to ride a camel at the head of the column for some ten days, as I was too weak to march. The poor grazing was telling severely on our camels, who became extremely emaciated and weak, so we began to kill the sickly ones for food purposes. Their condition was so wretched that our progress on the march was dismally slow. The small ration of grain to which the men were, of necessity, restricted also began to make itself felt, and for the first time demoralization set in amongst the transport drivers. These latter gorged themselves in such a bestial manner with every portion of a camel, including the hide, feet, blood, etc., that before long several of them showed signs of breaking up. On May 19 three Jehadia (transport drivers) died, whilst a fourth, in spite of repeated orders, went outside the camp zariba shortly before midnight, and came yelling back into camp with a spear-wound through him. He was carried on a donkey for several days before succumbing.

Time after time the men had been warned that our every movement was being watched by hostile natives, who, although unseen, were always lying in wait ready to spear any stragglers who might wander from the precincts of camp unarmed. Our men, more especially the Jehadia, were visibly suffering greatly for the want of carbohydrate food, as the supply of grain issued daily as a ration was extremely limited in quantity, and on meat alone they seemed quite incapable of maintairing their strength. Our line of march was daily hampered, in consequence, by our having to mount ten or eleven men on donkeys in rear to get them along at all. The fine discipline of the regular soldiers enabled them to carry out arrangements whereby they all messed together; but the other men so little trusted each other in their present straits that they fed independently, and therefore derived considerable less benefit from their rations. Ultimately, when our losses had become so sericus that there appeared grave doubts of our 
ever getting through, a general mess for the whole camp was insisted on, and proved much more satisfactory. On May 22 we camped for the last time on Lake Rudolf, and next day marched across country in a southerly direction to the river Turkwell, the sandy bed of which was half a mile wide where we struck it.

I have scmewhat abruptly dismissed our journey along the shores of Lake Rudolf, as I have previously written a description of that great reservoir. We found the water of the lake at a lower level than in 1898, due to the exceptional drought of the previous year, when the Omo river was quite dry. The water was far more nauseating than formerly, and the numerous lagoons we remembered as teeming with wildfowl of many varieties were to a large extent dry, and birds were conspicuous by their absence, so even this source of food was denied us; whilst big game is practically non-existent on the western shores of Rudolf, which constitute grazing-grounds for Turkana flocks and herds.

The Turkana were settled in large numbers along the Turkwell, but behaved in a most treacherous manner; although pretending friendship and conducting us some 5 miles down the bed to a waterhole, they seized the first opportunity and speared one of the donkeycorporals out on grazing guard. The man died next day. It was obviously useless trying to maintain any friendly relations with these people, which I was most anxious to do, seeing the weak state of the caravan.

In 1898 the Turkana of the Turkwell had harassed my column of $180 \mathrm{men}$, and caused much trouble and anxiety, owing to their repeated attempts on our transport animals whilst grazing. It may be imagined, therefore, that with one quarter of those numbers, and the larger majority of the men incapable of much active work, I did not at all relish the passage through their country under present conditions. There was no alternative, however, and our one chance of salvation was to exercise extreme caution, and to give as little opportunity as possible for the Turkana to do us serious damage.

We continued west along the Turkwell, marching in the bed of the river, as the banks were thickly wooded and afforded too much cover for an active foe to be pleasant for us. Daily the condition of our men became worse, and I am not using too strong an expression to describe our progress on the march as perfectly appalling. We had previously cast away many loads, to lighten the work of our men, into the lake, and on May 24 a further large consignment of tents, trophies, spare saddles, and many other things no longer indispensable, were committed to the flames. On May 27 we had a dreadful march, and four men died after we had got them into camp. It would become monotonous were $I$ to proceed to describe our daily worries and anxieties regarding the men and transport animals, so I will pass as rapidly as 
possible over our horrible experiences, on which one little cares to linger. The ever-present Turkana following us incessantly greatly added to our difficulties.

On reference to my diary, I find that so early as June 2 sixtcen of the Jehadia had either died or been killed; one servant had died, and another been killed; whilst two askaris had been killed, and one had died. Our original force of fifty-nine blacks all told had been reduced to thirty-eight already.

Travelling along the Turkwell was always an unpleasant and anxious business, as the thick forest growth and dense vegetation bordering the banks made progress along the river almost impossible. We were compelled, therefore, every day, either to proceed up the bed, now containing a running stream about knee-deep, which was a very laborious undertaking; or, on leaving camp, to strike away from the river through a thick belt of thorn and dwarf palm to the higher ground, which was more open, but thickly covered with wait-a-bit thorn. Proceeding along the higher ground in a southerly direction, about 11 a.m. we used to turn off in a south-westerly one, with a view to reaching the river-bank again to camp. This was always the most anxious part of the day's march, as one never knew what dense growth we might have to encounter, or when we were likely to reach the bank of the stream, which takes a most erratic northerly course to about $3^{\circ} 6^{\prime} \mathrm{N}$. before swinging east towards Lake Rudolf. With a professional guide, in 1898 we had on several occasions spent two or three hours finding the river again towards the end of a day's marcb, being frequently badly hung up by the thick nature of the country, which prevented our forcing a way through.

On the whole, during our present journey south along the river, we met with extraordinary good fortune in our endeavours to get down to the water, and were not often badly involved. Our progress, however, was funereal in the extreme, owing to the debilitated state of the men (some ten or a dozen of whom were being daily carried on donkeys), which left very few partially sound men to drive the animals and look after them in this much-enclosed country. Day after day we crawled along, and on June 11 reached the outskirts of the Ngaboto districtthe most southerly one of the Turkana-which was densely populated by natives. Dura was growing in quantities along the river-bank, but was all green and unfit for food, so we could obtain no grain, much to our disappointment, as we had hoped against hope to be able to purchase a little here. On June 13 we crossed the river Weiwei, which flows from the south into the Turkwell, and began to breathe again, as we trusted that we had seen the last of the Turkana, their country terminating hereabouts. They treated us to a parting shot though, by spearing the best of our remaining Jehadia that day just before dark, He foolishly crossed the river unarmed to look for 
a missing donkey, when presently we heard the most blood-curdling yells, and, rushing to the river-crossing, found him lying dead midstream with four spear-thrusts through him. The Turkana had disappeared, of course, like magic through the thick vegetation.

We halted to rest the expedition next day. Our numbers were now reduced to thirty-two, out of the total of sixty-two (including our three selves), whilst our transport animals consisted of five mules and seventysix donkeys. As soon as the camels had all died and been eaten, we had at once commenced eating donkey-flesh towards the end of May. Until we reached the Baringo post at the beginning of August, this was the sole meat supply we all enjoyed.

We now struck away from the Weiwei river in a south-westerly direction towards the foot of the Suk hills, which are a northerly continuation of the Elgeyo range. Our first march from the Weiwei was the most disastrous one of the whole journey, no less than six men collapsing in spite of the previous day's halt. Several of these, we were aware the previous evening, would not last out the march, in spite of being held on to donkeys; but we never contemplated quite such a collapse. We camped on the bank of a fine running stream that day, and I way here incidentally mention that I shot two vultures that were rather annoying. To my utter astonishment, there was a rush for these loathsome carrion, which were quickly plucked and boiled and subsequently devoured! We still continued in a southerly direction along the foot of these mountains, and experienced difficulties again regarding water until we reached the most northern Suk settlement of Sekere on June 17.

Here for the first time I noticed an extraordinary, to me, number of purple spots all over my legs, which I showed to Dr. Garner. A few days later, hæmorrhage of my mucous membranes set in, and I became in course of time so seriously ill with scurvy that I almost succumbed to this disease.

On June 20 we reached Marich, so familiar to Major Bright and myself, as we had previously visited this place in 1897, and again in 1898 . Throughout the dreadful journey south we had always tried to buoy up the hopes of the men and ourselves by saying that once we reached Marich we would be safe, as food would be obtainable in abundance. There was none obtainable. The former smiling fields of grain we remembered so well had all disappeared, and their place was taken by long coarse grass and rank vegetation. The natives were no longer the prosperous ones they were. They were quite friendly, however, and we obtained the services of a Suk youth, who had a smattering of Ki-Swahili, and informed us that he knew the site of the Ribo post, to which he would conduct us in return for a present of two goats; to this we readily assented. I should like to meet that guileless youth again, as, after conducting us for several days to a point a few miles 
south of the Kivas district, and landing us in a most atrocious bit of country, he quietly gave us the slip whilst tending our goats and sheep midst long grass after we had camped. His absence was not discovered until evening, when all the animals were brought in as usual to camp; then it was found that not only was he missing, but seven goats also, including all our milch ones! Needless to say, we never saw him again; but I live in hopes that we may meet again some day, when I may have a few points to discuss with that cherub boy.

On the Suk youth departing, we found ourselves involved in a most difficult tract of country along the lower slopes of the mountains, much broken by small ravines and mountain torrents, the banks of which were clothed in tall rank vegetation. We proceeded with much labour, as I could find no tracks through this dense growth until eventually we reached a well-populated district, known, I believe, as Chemtubell or Ndao. This place was reached in a state bordering on collapse. Our numbers had been reduced to seventeen blacks, most of whom were utterly exhausted, as were also the transport animals after our last few days' experiences, whilst my condition also was causing a certain amount of anxiety. All we now had left for the men was some 15 to 20 lbs. of grain we had a few days previously purchased from the Suk at Kivas.

In spite of our unpleasant position, we were obliged to have a rest, and, as we were camped midst cultivation, we proceeded to try and get the natives to bring in grain for sale. Our efforts met with little success for the first two days ; but our luck changed with the advent of the month of July. We still had some five sheep left, which we had reserved for such a contingency, and as the natives would not look at beads, we slaughtered our sheep and exchanged meat for heads of nearly ripe grain.

Who these natives were we could never ascertain. Their hamlets, like those of the Suk, were built high up on the hillsides, and their fields were irrigated in a similar manner to those of their northerly neighbours. They are possibly an offshoot of the Wa Elgeyo, and utilized bows and arrows in preference to spears.

It was not until July 10 that we made a fresh move forward, and on that day we marched some 5 to 6 miles in an easterly direction to the river Kerio, which was crossed with considerable difficulty. Thence we continued in a south-easterly direction across the Suk plains with the object of hitting off a pass in the hills, where the plains terminate to the south. It was most necessary to find this point, as the success of our journey south towards Lake Baringo depended almost entirely on our finding it, and water in the valley of the Karuan beyond. We were delayed some days in crossing this plain, owing to relapse from nasal hæmorrhages from which I suffered, and only proceeded slowly in consequence. In spite of this, two more askaris and my servantNo. VI.-June, 1902.] 
Hanna, the last of our personal attendants-collapsed, and when, on July 20, we reached one of our old 1897 camrs at Kisite, only fourteen blacks now remained with the column. Here for a week I was at death's docr, suffering from the most severe lelapse I had yet experienced.

We were delayed, therefore, until July 29, before I could continue the painful journey, riding now a donkey until we reached safety. During this l.ng detention, large flocks and herds were brought daily by the Suk to be watered at the pools near which we were camped-at the mouth of a gorge, issuing from the hills. Among the Suk who visited us was a Jouth who had a fairly fluent knowledge of Ki-Swahili, and from him we heard of the existence of a post at the south end of Lake Baringo, occupied by Europeans. We placed little reliance on his asserticns, as we had quite made up our minds that we should have to struggle through somehow to the Ravine station, but at the same time were glad to obtain his services as guide. On starting off again, we were accompanied by him for tbree marches to the north-west corner of Lake Baringo. From this point he wished to take us round the east of the lake to the post, in the existerce of which he persisted.

We were sceptical, so decided to procecd by the more direct route to Njemps, along the western shore of the lake. The guide asked permission to return to his father's home by the eastern route, and readily agreed to take a note, with which Major Bright supplied him, to the Baringo post. We commenced our journey along the western shores of Baringo on August 1, camped that night on the lake-shore, and continued in a southerly disection \& gain next day. I had hoped we might find water in the river Ndo, which flows from the Kamasia range of mountains to the west into the lake. We reached the bed of this stream, amidst thick bush, some miles from the lake-shores, but found it absolutely waterless. It was now about ten, so we decided to make a short halt before proceeding in an easterly direction towards the margin of the lake. We had thought little more of the note that had been despatched; but whilst we were resting under trees, some of the men in rear reported that a white man was riding after us on a pony, accompanied $k y$ askaris, carrying small bags of flour on their heads.

The news appeared too good to be true after all the disappointments we had met with; but presently the white man was in our midst, and proved to be Mr. Hyde-Baker, the collector of the Baringo district, who conducted us to his post some 10 miles distant. A fatted ox was slaughtered for our men that night, and the poor survivors enjoyed such a meal as they had not tasted for many a weary day past. It would never be necessary now again to kill a wretched donkey for food, as $\mathrm{Mr}$. Hyde-Baker could supply rations of a more congenial nature. 
The extraordinary energy and dogged perseverance of $\mathrm{Mr}$. Hyde. Baker had rescued us from a most desperate position. He had received the note from the Suk youth the previous day, in which our straits were clearly described, and had started an hour and a half later with a small party of men to look for us. Continuing all that day until dark, he wandered along the western shores of the lake to the north end, where he found one of our old camps. Knowing that he must havo missed us, he retraced his footsteps next day, came across our tracks, and literally hunted us down until he came up with us. The debt of gratitude that we all owe to him in succouring us will not readily be forgotten.

For the next twelve days we passed a peaceful existence on the summit of an isolated hill overlooking the lake, where Mr. Hyde-Baker had established his post. The luxury of obtaining milk, eggs, and bread again was highly appreciated, and we enjoyed much hospitality besides from our host. Mr. Hyde-Baker kindly arranged to fit out a complete caravan of his own with fresh animals under charge of some twenty to thirty of his own men, in order to convey us and our stores to the railway at Lake Nakuru.

We all left Baringo post on August 14, and in due course reached the railway at Lake Nakuro on the 21 st, some 75 miles distant. On August 24 we commenced our railway journey, and on the morning of the 26th reached Mombasa, covering the 450 miles in two days, which in former times used to occupy as many months marching.

We sailed from Mombasa on September 8, and on the afternoon of the 16th reached Aden. Here we remained until September 22, when we sailed again for Suez in the Austrian-Lloyd boat Silesia, reaching our destination on the night of September 27. The following day we journeyed by train to Cairo, where Sir Rennell Rodd and a large number of officers had most kindly come to the station to welcome back those who had passed safely through such dreadful experiences.

'T'wo days later I accompanied the survivors of the 10th Sudanese to Assuan, where the men met with a most cordial and stirring reception, not only from their commandant and officers, but from the whole battalion, who were awaiting the arrival of the train at the station. The regimental band played them back to the lines they had left some ten montbs before, and the shrill lu-luing of the women intensified the emotion of those splendid fellows. Such a reception must indeed have gone far to obliterate, temporarily only perhaps, the memory of that hideous time, when they had suffered so much, and yet which they had faced with such fortitude and determination, and a firm resolve to get through at all costs. I owe those men much. Had it not been for their loyal and exemplary behaviour, and the grand way in which they worked, none of us would ever have been heard of again -alive. Having arranged with Hunter Bey all details regarding pay 
etc., of the men, and bringing to his notice the names of those especially deserving of recognition, it was my sad duty to wish them all a long good-bye and return to Cairo on October 3. A week later, Major Bright, Dr. Garner, and I were on the high seas bound for England, where we arrived on October 15, 1901.

Before the reading of the paper, the President said : Many here present will no doubt remember the papers that were read three years ago by Colonel Macdonald and Major Austin giving a most interesting account of their very successful work, and especially of Major Austin's work along the western side of Lake Rudolf. Since that time Major Austin has been very actively employed, and he has now made a most remarkable journey, during which there were very great hardships and sufferings to be endured, from the Nile to Mombasa. I will now ask Major Austin to read his paper.

After the reading of the paper, the following discussion took place :-

Major BRIGHT: Major Austin having given you a graphic description of our journey of some 2400 miles through British territory, from Omdurman to Mombasa, I will confine myself to saying a few words on the geographical features of the country through which we passed, from the swampy regions of the Nile to the magnificent highlands of British East Africa. They are of absorbing interest. The great Abyssinian plateau, which, roughly speaking, lies north and south, bounds a large plain extending several bundreds of miles to the Nile. In this plain there are small ranges of mountains rising abruptly from the surrounding country. The natives inhabiting this region are suspicious and very shy, which is not to ke wondered at, as they are constantly harried and raided by the Abyssinians. While passing through the Musha district we frequently saw the tracks of flocks and herds, and sometimes came across a few sheep and goats, but never met with a human being. We spent some time in the neighbourhood of the Omo, which is by far the finest river in this part of Africa, and the sole perpetual feeder of Lake Rudolf. Its banks are clothed with fine trees, and some parts are extensively cultivated by the natives. This is a valuable piece of country, not only for its fertility and timber, but for its supply of fresh water, that of Lake Rudolf being far from good.

As the remainder of our journey had been previously sketched by Major Austin, he here closed his survey with the most satisfactory results on his position of 1898 . Observations had been taken by him nearly every night with a $5^{\prime \prime}$ theodolite for latitude and time, and as we had carried with us chronometer watches, the positions of our camps were generally fixed in this way. He had mapped our route with thousands of bearings with a prismatic compass, and used pedometres with satisfactory results. The methods of azimuths and latitudes were frequently used, the former being taken from points he had fixed. The map was plotted at 4 miles to 1 inch. The heights of mountains were determined by theodolite observations from data supplied by aneroids, and thus the map you have now before you was compiled. The country on the north-west of Lake Rudolf is an open plain with a few stunted trees. The beach is composed of black sand-this is evidently the reason why it is called by the Swahilis the "Black lake"-whereas Lake Stephanie, whose shores, I have been told, are of white sand, is termed by them the "White lake." Before reaching the Turkwell river, the country becomes a dreary desert, and there are steep cliffs rising from the beach. The Turkwell has its source in the extinct crater of Mount Eigon, and is joined by the river Wei Wei, but their united waters never reach the lake, being gradually absorbed by the porous soil. Following this river 


\section{LAND Journey From Nasser to the Uganda RaILW By \\ Brevet Major H.H. Austin, C.M.G., D.S. $1900-1901$.}

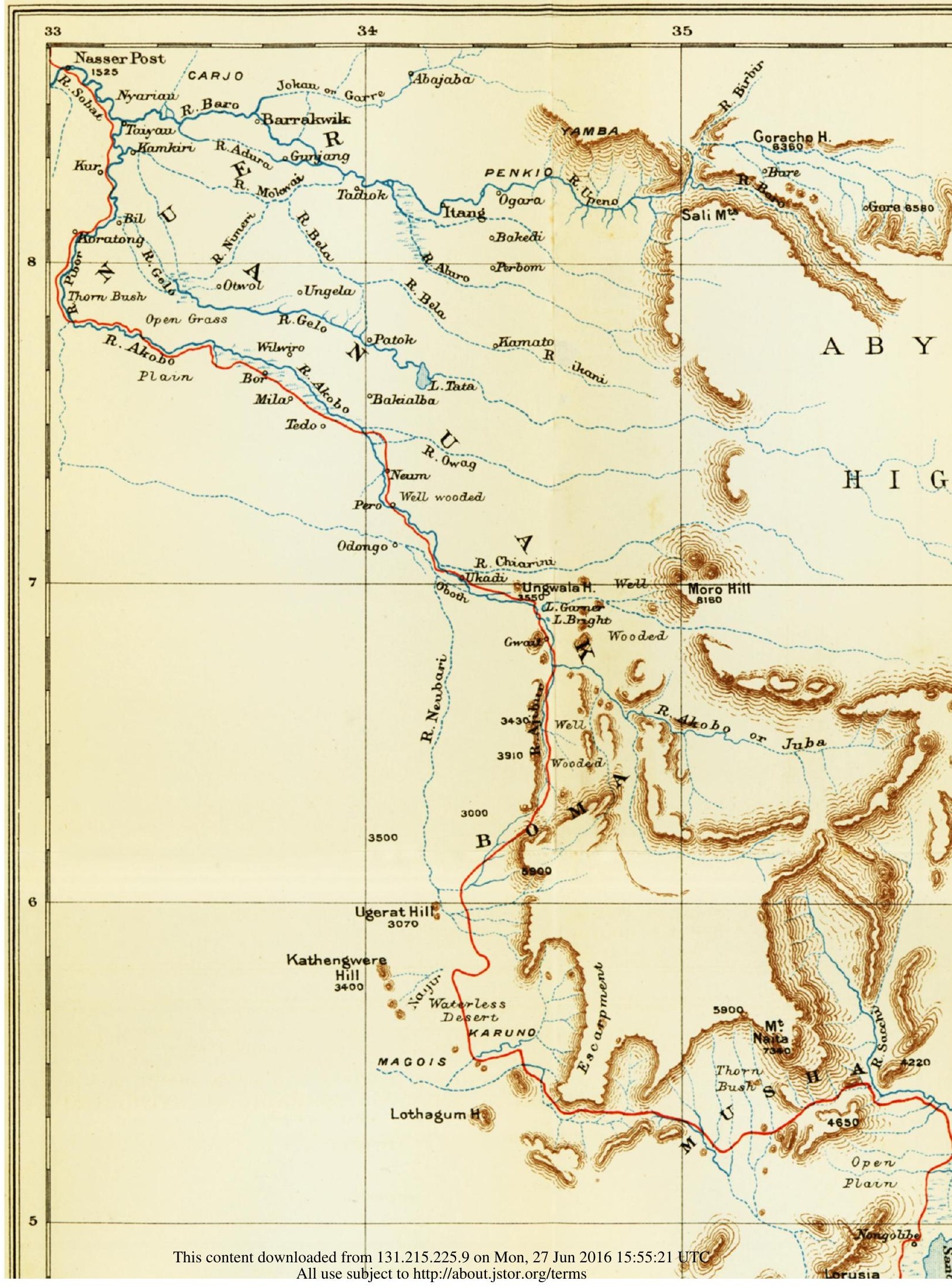


